\title{
Qualitative and Quantitative Analysis of Environmental Damages through Instauration and Registers of Lawful Documents
}

\author{
Roberta Hehl de Sylos Cintra*, José Eduardo dos Santos, Luiz Eduardo Moschini, José \\ Salatiel Rodrigues Pires and Carlos Henke-Oliveira \\ PPG-ERN; UFSCar; Via Washington Luiz, Km 235; C. P. 676; 13565-905; São Carlos - SP - Brasil
}

\begin{abstract}
A qualitative and quantitative analysis of the environmental damages occurrences was conducted through the lawful documents established for charging at the State Prosecution Service of São Carlos city, State of São Paulo, during 1991 - 2000, to understand the relationship between environmental problems and the current development actions. The environmental damage identified were grouped into nine classes, where deforestation was prevailing in each year along the period of study. Of the total number of deforestation occurrences, 180 was related to areas smaller than 5 ha. It corresponded to 110.35 ha of the total deforested area. The other 37 were associated with areas higher than 5 ha, equivalent to 1,013.27 ha. The registers of environmental damages in the period in a rough estimate, corresponded to a mediam loss of $5.91 \pm 4.14$ ha/occurrence and of $112.36 \pm 91.73$ ha/year of deforested area.
\end{abstract}

Key words: Environmental damages; deforestation; lawful documents

\section{INTRODUCTION}

The demographic, economic and social changes exert considerable pressure on the fragmentation and loss of natural forested areas (Achard et al., 2002), jeopardizing the environmental functions of the ecosystems (De Groot, 1992), the loss of habitat and biodiversity (Mac Arthur and Wilson, 1967; Harris, 1984; Dobson et al., 1997) and a series of environmental consequences related to global, regional and local climatic changes (Achard et al., 2002). The history and the speed of deforestation related to expansion of agricultural border changed the dynamics of remaining forests in the Northeastern region of São Paulo State, without being followed by any conservation strategy.
Many municipalities of this region have lost more than $50 \%$ of their natural forested areas, as a result of the expanding agricultural border, with levels of reduction similar to those observed for the Atlantic Forest, currently around $7.3 \%$ of its original coverage (SOS Mata Atlântica; INPE and ISA, 1998). This current landscape is restricted to fragments dispersed among crop/livestock farming, urban, mining and agroforestry areas, subjected to an intense process of ecological impoverishment (Viana et al., 1997). Although they are opposites, the conservation strategies and the environmental damages must be discussed in the perspective of proposal guidelines for the regional sustainable development, to be integrated in the municipal environmental planning. However, it is necessary to use concrete

\footnotetext{
${ }^{*}$ Author for correspondence
} 
instruments to restore the balance of values between human activities and natural resources. In this context, the environmental lawful protection appears as a way to guarantee the preservation of natural resources, once the environmental deterioration is a threat to environmental and life quality. It becomes fundamental that the legislation in force is potentially able to synchronize the need of exploring the natural resources and the environment preservation, aiming economic development.

The organization of a database based on the environmental impacts resulting from development practices in the federal, state and municipal levels became essential to support the environmental and life quality of the urban and rural environment (Graf, 1998). The conduction of works related to the identification and register of these occurrences in the regional landscape has been fundamental to guide the local development policies adequately. The public lawful registers became an efficient tool to obtain such data, mainly due to the easy access and veracity of the information. However, this is not enough for a real environmental diagnosis, since not all environmental damages occurrences in the municipality are registered through lawful documents.

The objective of this work was the qualitative and quantitative analysis of the environmental damages occurred in the Administrative Region of São Carlos, SP, through the organization and analysis of a database regarding the lawful documents of instauration and charging at the State Prosecution Service, in the period of 19912000, to identify the relationship between number and types the environmental damage occurrences and the current development actions in the municipality landscape.

\section{METHODOLOGY ADOPTED}

The study area encompassed the Administrative Region of São Carlos, delimited by the São Carlos municipality and by the districts of Água Vermelha and Santa Eudóxia, situated in the central region of the State of São Paulo between coordinates $47^{\circ} 30^{\prime}$ and $48^{\circ} 30^{\prime} \mathrm{W}$ and $21^{\circ} 30^{\prime}$ and $22^{\circ} 30^{\prime} \mathrm{S}$ (Fig. 1), and between the altimetric quotas of 500 to 1000 meters. The São Carlos municipality covered an area of 114,390 ha, and about 4,803 ha of urban and 109,587 ha of rural area. The population was 192,998 inhabitants, with 183,433 in the urban and 9,565 inhabitants in the rural area (IBGE, 2000). São Carlos has one of the highest per capita incomes in the São Paulo State, comprising about 60 industries of high technology, especially in the sectors of agricultural and mechanical industry, textile, orthodontics material and medical devices (IBGE, 2000). The county also participates in the agricultural-pasture-forest sector, integrating an important milk production basin called "the milk belt" (SÃO CARLOS, 2000).

\section{Methods}

The environmental damages survey in the São Carlos municipality in the period from 1991 to 2000 was carried out through the consultation of lawful documents registered in the Civil Court House of the Administrative Region of São Carlos, of the State Prosecution Service, at the Public Prosecutor's Office responsible for the defense of the environment relevant to the $7^{\text {th }}$ and $5^{\text {th }}$ Curatorships. These registers of lawful documents resulted from routine inspections or investigations made by the Department of Protection of the Natural Resources (DePRN) and/or by the Environmental Military Police, both headquartered in São Carlos Administrative Region, and also from the action of the Company of Environmental Sanitation Technology (CETESB). In many cases, the routine inspections are related to denouncement of environmental damages made by citizens or by non-governmental organizations of environmental protection.

In the State Prosecution Service, the registers generate, firstly, an Administrative Procedure (AP) to analyze the environmental damage and its solution with the infringer, aiming to repair the effects of the environmental impact. If an agreement is not possible, or if the infringer refuses to agree on the settled terms, the registers are sent to the pertinent court for the instauration of a Public Civil Suit (PCS). All AP and PCS registered respectively in the Public Prosecutor's Office and in the Civil Court of the Administrative Region of São Carlos, whose instaurations dated in the period of 1991 to 2000, were analyzed.

In order to prepare the database, each AP and/or PCS received a code number that characterized the stage in which the lawful document was and the agency responsible for following it. Other informations were also collected: instauration date of the register; name of the responsible for the 
notification; the responsible person or owner; date of the environmental impact or charging; description of impacted area; kinds of environmental damages; extension of the damage; consequences and measures to repair the damage; additional information and the date when the lawfull document was filed in case it was processed. The types of environmental damages were classified according to the environmental legislation, involving details referring to the place, the kind of material used in the infringement, the category of legally protected area, the kind of water resource, and the kind of law infringed (lack of registration of the Legal Reserve, lack of license of operation, lack of respect to the legal limits for burning sugar cane, among others). The environmental damage classification involved also subjective aspects and specific understandings of the researchers.
The environmental damages that prevailed was analyzed in qualitative and quantitative terms of its distribution along the period of study, in relation to the extension of the impacts, the nature of the infringer agent and its classification in the pertinent legal system. The environmental damage related to deforestation registers were georeferenced with a GPS (Global Positioning System) receptor, transferred to the MapInfo sofware, and then overlayed on thematic maps of rivers, roads network and land cover restricted to natural and semi-natural vegetation areas of São Carlos municipality. These thematic maps were previously generated by MapInfo and made available by the Laboratory of Environmental Analysis and Planning of the Federal University of São Carlos.

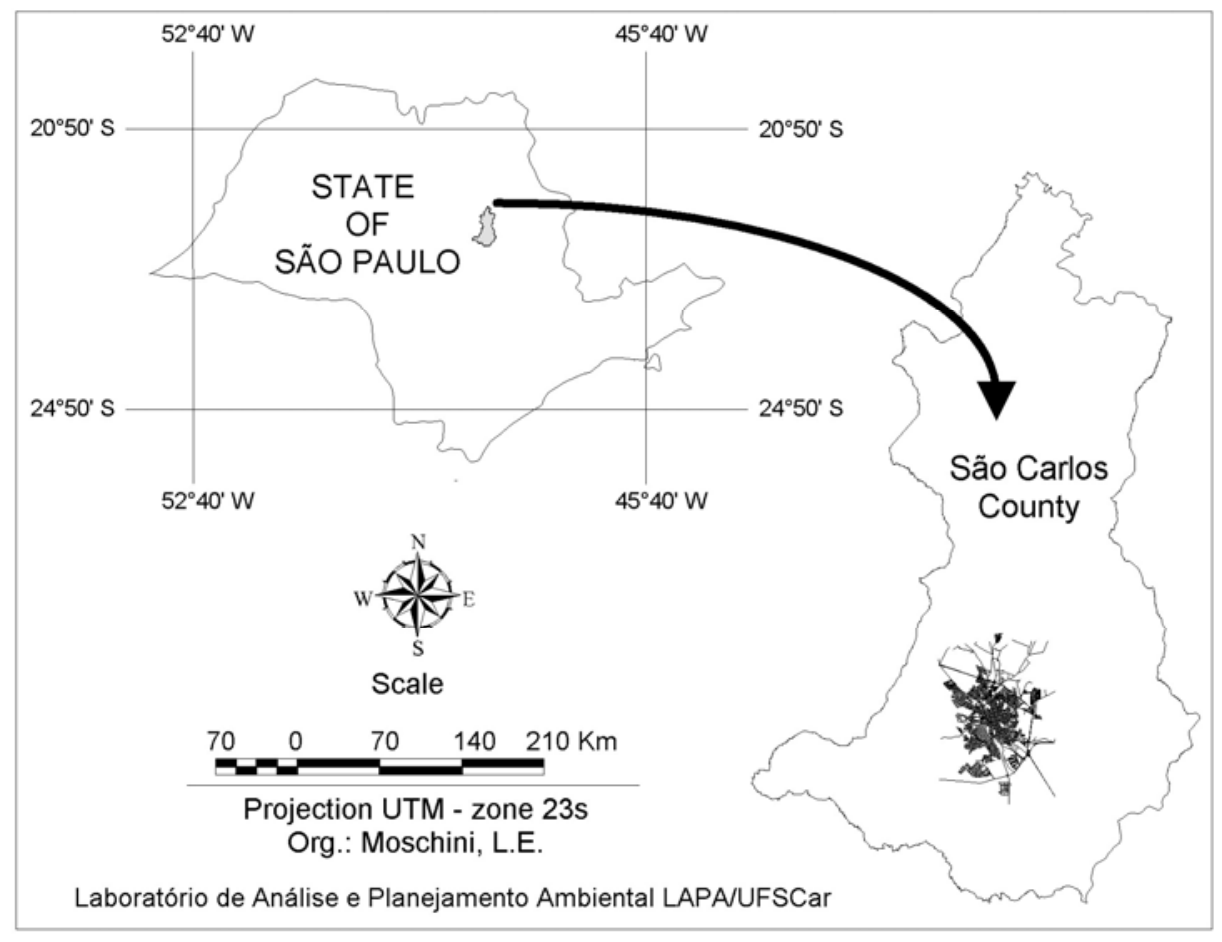

Figure 1 - Geographical location of the São Carlos county, São Paulo State.

\section{RESULTS AND DISCUSSION}

In the period of 1991 to 2000,385 occurrences of environmental damages were registered, comprising 358 Administrative Procedures (AP) and 27 Public Civil Suits (PCS) (table 1). The database including the total environmental damage registers and their respective elements of identification are available at http://lapa.ufscar.br. The registers involving AP and PCS together, were classified into nine classes: damages to historical landmarks, damages to biota, damages to water resources, irregular deposition of garbage, deforestation, rules infringement, irregular 
disposition of soil, air pollution and sound pollution (Table 1). This classification enabled that more than one modality of registers, related to water resources, for example, were grouped in the same class of impact.

Deforestation was the prevailing environmental damage, both in relation to the AP and the PCS, in each year and along the period of study (Table 1). This class included all registers of infraction referring to the elimination of vegetation and impediment of its regeneration. Although not identified in the infraction and register of the environmental damage, deforestation was associated with areas of cerrado (scrub and field savanna), cerradão (arboreal savanna), semideciduous forest, riparian forest and secondary vegetation. This category of damage also included the legal categorization of the areas in terms of Permanent Protection Area (APP), Environmental Protection Area (APA) and Legal Reserve (RL). The second prevailed class of environmental damages was represented by rules infraction (Table 1), making evident the ignorance or lack of respect to environmental laws. However, it must be considered that the legislation is not known by everyone, mainly by small infractors, although the allegation of ignorance does not exempt the infringer from blame and the consequent responsibility for the environmental damage.

The total number of deforestation occurrences per year made evident an heterogeneous distribution along the period of study. Atypical years such as 1993, 1994 and 2000 reflected the prevalence of a lower number of occurrences, however related to higher values of deforested areas, respectively of 197.35, 271.76 and 229.47 ha, whereas in 1997, the registers pointed out the highest number of occurrences associated with the smaller occurrences (129.47 ha) of deforested area (Fig. 2).

Of the total number of deforestation occurrences (Table 1), 217 presented complete information about deforested areas values (Table 2). Of this, 180 were related to areas < than 5 ha, with predominant action of Privy Persons (126) in relation to Corporation Entities (53), corresponding to 110.35 ha of the total deforested area in the period of study. The remaining 37 occurrences were related to areas $>$ than 5 ha and were responsible for $1,013.27$ ha of the total deforested area. This included also, the Corporation Entities, involving 16 occurrences with a value of 533.35 ha of deforested area.

Table 1 - Quantitative and qualitative classes of environmental damages involving Administrative Procedures (AP) and Public Civil Suits (PCS) registered in the Civil Court of the Adminstrative Region of São Carlos in the period of 1991 to 2000.

\begin{tabular}{|c|c|c|c|c|c|c|c|c|c|c|c|c|c|}
\hline $\begin{array}{c}\text { Classes of } \\
\text { environmental damages }\end{array}$ & $\mathbf{A P}$ & PCS & $\bar{\sigma}$ & ڤ̆ & ڤิ & बूे & 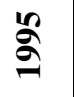 & よั & $\hat{\sigma}$ & $\stackrel{2}{\sigma}$ & बे & ఫิ & Total \\
\hline $\begin{array}{l}\text { Damages to historical } \\
\text { landmark }\end{array}$ & 2 & 0 & 0 & 0 & 0 & 0 & 0 & 0 & 1 & 0 & 0 & 1 & 2 \\
\hline Damages to biota & 6 & 0 & 0 & 0 & 0 & 0 & 0 & 0 & 1 & 1 & 2 & 2 & 6 \\
\hline $\begin{array}{l}\text { Damages to water } \\
\text { resource }\end{array}$ & 28 & 3 & 3 & 2 & 2 & 1 & 0 & 3 & 0 & 9 & 8 & 3 & 31 \\
\hline $\begin{array}{l}\text { Irregular deposit of } \\
\text { garbage }\end{array}$ & 31 & 0 & 1 & 1 & 1 & 2 & 1 & 4 & 3 & 7 & 7 & 4 & 31 \\
\hline Deforestation & 224 & 21 & 7 & 6 & 17 & 27 & 27 & 20 & 53 & 26 & 26 & 36 & 245 \\
\hline Rules infraction & 33 & 1 & 0 & 1 & 2 & 2 & 1 & 3 & 3 & 6 & 8 & 8 & 34 \\
\hline $\begin{array}{l}\text { Irregular disposition of } \\
\text { the soil }\end{array}$ & 3 & 0 & 0 & 0 & 0 & 0 & 0 & 0 & 2 & 0 & 1 & 0 & 3 \\
\hline Air pollution & 10 & 1 & 1 & 1 & 0 & 0 & 2 & 1 & 1 & 1 & 2 & 2 & 11 \\
\hline Sound pollution & 21 & 1 & 2 & 0 & 2 & 3 & 1 & 2 & 4 & 3 & 3 & 2 & 22 \\
\hline Total & 358 & 27 & 14 & 11 & 24 & 35 & 32 & 33 & 68 & 53 & 57 & 58 & 385 \\
\hline
\end{tabular}


Table 2 - Total number of deforestation occurrences related to type of responsible person or owner and to values of deforested areas (<5 ha and > 5 ha) in the São Carlos county in the period $1991-2000$.

\begin{tabular}{|c|c|c|c|c|}
\hline $\begin{array}{l}\text { Kind of responsible } \\
\text { person or owner }\end{array}$ & $\begin{array}{l}\text { Number of deforestation } \\
\text { occurrences with } \\
\text { extension values }<5 \text { ha }\end{array}$ & $\begin{array}{l}\text { Total value } \\
\text { of deforested } \\
\text { area (ha) }\end{array}$ & $\begin{array}{c}\text { Number of } \\
\text { deforestation } \\
\text { occurrences with } \\
\text { extension values }>5 \text { ha }\end{array}$ & $\begin{array}{l}\text { Total value of } \\
\text { deforested area } \\
\text { (ha) }\end{array}$ \\
\hline Privy Person $(\mathrm{PP})^{(*)}$ & 126 & 73.85 & 21 & 479.92 \\
\hline $\begin{array}{l}\text { Corporation Entity } \\
(\mathrm{CE})^{(* *)}\end{array}$ & 53 & 34.0 & 16 & 533.35 \\
\hline Universality (U) ${ }^{(* * *)}$ & 1 & 2.5 & -- & -- \\
\hline Total & 180 & 110.35 & 37 & $1,013.27$ \\
\hline$(\%)$ & 82.9 & 9.8 & 17.1 & 90.2 \\
\hline
\end{tabular}

\footnotetext{
${ }^{(*)}$ Refers to environmental damages resulting from actions of a particular person.

${ }^{(* *)}$ Refers to environmental damages resulting from actions of companies.

${ }^{(* * *)}$ Refers respectively to individuals whose activity is related to the family subsistence or recreation; to companies that aim the economic exploration of natural resources, or to a set of property that, in a certain special and temporary situation, receives a corporate entity so as to fulfill an economic and legal objective, becoming responsible for legal acts performed (De PLÁCIDO e SILVA, 1999).
}

The 217 registers of environmental damages in the period 1991 to 2000, involving deforested areas < and $>$ than 5 ha determined a total loss of $1,121.62$ ha of natural and semi natural vegetation in São Carlos county (Table 2). In a rough estimate, this corresponded to a mean loss of $5.91 \pm 4.14$ ha/occurrence and of $112.36 \pm 91.73 \mathrm{ha} /$ year of deforested area. These mean losses values were not representative for the 217 deforestation occurrences along 10 years, due to the extreme heterogeneity of the deforestation values, reflecting in a high variation coefficient $(70 \%$ and $81 \%$, respectively). This variability seemed to be conditioned much more to the values of deforested areas and to the legal profile of the responsible person for the environmental damage, than to the number of occurrences during the period of study. The highest value of deforested area was related to Legal Entities (Table 2), constituted by companies, sugar and alcohol plants, big farmers and cattle raisers. It reflected the immediate interaction between environment and development in terms of environmental damages resulting from the local producing activities, particularly of the agricultural industries.

Only 189 registers of occurrences with a total extension of 1,013.08 ha of deforested areas, < and $>$ than 5 ha in the period of 1991-2000, were categorized in terms of legally protected areas by the Brazilian environmental legislation like a Permanent Preservation Area (APP),
Environmental Protection Area (APA) and Legal Reserve (RL). There was a prevalence of environmental damages in APP areas, when compared to APA and RL areas, both in number of occurrences and values of deforested areas < and $>$ than 5 ha (Table 3). Although the number of occurrences related to the Corporation Entities was smaller to the actions performed by privy persons, both kind of infractors did not differ significantly in relation to the losses values of legally forested areas, < and > than 5 ha. However, the actions related to privy persons and by Corporation Entities related to the total of deforestation value in APP areas (749.91 ha), were much more worrying to the landscape environmental quality, both because of loss of riparian vegetation and biodiversity than those observed for APA (134.55 ha) and RL (128.62 ha) (Table 3), and also in relation to the water quality by soil erosion in areas of hills and slopes.

At least 127 deforestation registers were georeferenced corresponding to $55 \%$ of the total of occurrences, including the APP, APA and RL categories, with values < and $>$ than 5 ha. Of this, 37 registers included all deforested areas $>$ than 5 ha, whose properties were entirely located in the rural zone of São Carlos municipality. The 90 remaining registers corresponded to a random sample of deforested areas < than 5 ha (Fig. 3).

The geographic location of these deforested areas was basically associated with the river network 
headwaters and the riparian vegetation. This was particularly evident for the Chibarro river severely affected by deforestation next to its river-head (Fig. 3). A great number of deforestation occurrences around the road network it was also observed, particularly along the Washington Luiz Highway (SP 310) (Fig. 3), showing it as the main road of access of the responsible agencies for the infraction of denounced or routinely inspected areas. The remaining vegetation in 1997 in natural and seminatural condition was restricted to 487 fragments, excluding those smaller than one ha, with the prevalence of the size class between 1 to 5 ha, totalling 16,469 ha and corresponding to $14.4 \%$ of the total São Carlos municipality area (Fig. 4).

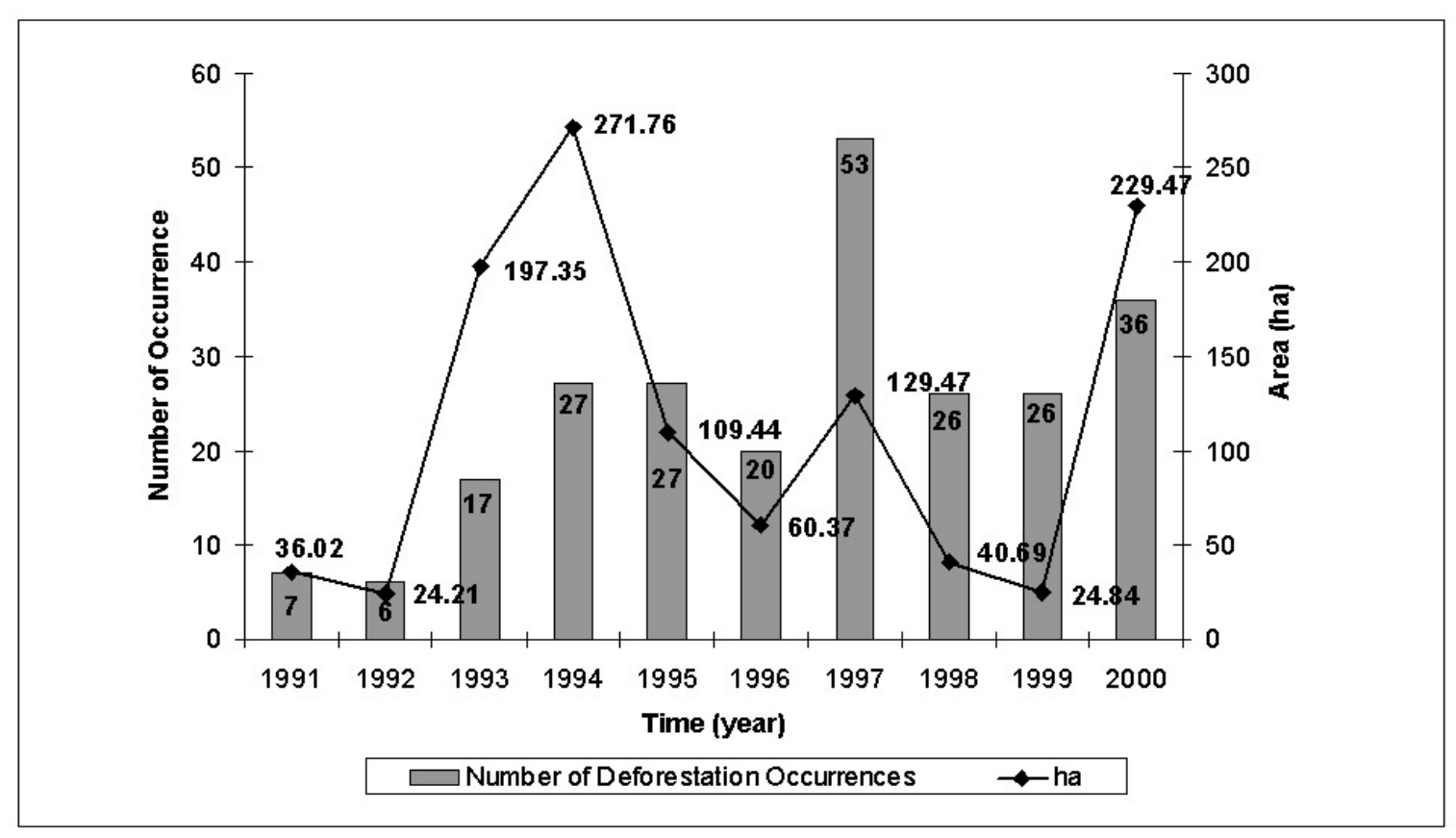

Figure 2 - Number of deforestation occurrences and total values of deforested areas based on the analysis of lawful documents related to environmental damages in the São Carlos county, during the period from 1991 to 2000 .

Table 3 - Qualitative and quantitative occurrences of deforested areas, $<$ and $>$ than 5 ha, related to type of infractor and to kind of legally protected areas: Permanent Preservation Area (APP), Environmental Protection Area (APA) and Legal Reserve (RL), in the period of $1991-2000$.

\begin{tabular}{|c|c|c|c|c|c|c|c|c|c|c|c|c|}
\hline \multirow{3}{*}{ Type of infractor } & \multicolumn{4}{|c|}{ APP } & \multicolumn{4}{|c|}{ APA } & \multicolumn{4}{|c|}{ RL } \\
\hline & \multicolumn{2}{|c|}{$<5$ ha } & \multicolumn{2}{|c|}{$>5$ ha } & \multicolumn{2}{|c|}{$<5$ ha } & \multicolumn{2}{|c|}{$>5$ ha } & \multicolumn{2}{|c|}{$<5$ ha } & \multicolumn{2}{|c|}{$>5$ ha } \\
\hline & $\mathbf{n}^{\circ}$ & ha & $\mathbf{n}^{\circ}$ & ha & $\mathbf{n}^{\circ}$ & ha & $\mathbf{n}^{\circ}$ & ha & $\mathbf{n}^{\circ}$ & ha & $\mathbf{n}^{\circ}$ & ha \\
\hline Privy Person (PP) $)^{(*)}$ & 35 & 36.44 & 36 & 325.92 & 13 & 6.32 & 2 & 89.00 & 32 & 10.30 & 4 & 59.00 \\
\hline $\begin{array}{l}\text { Corporation Entity } \\
(\mathrm{LE})^{(* * *)}\end{array}$ & 43 & 22.73 & 11 & 362.32 & 5 & 3.43 & 1 & 35.80 & 3 & 2.32 & 3 & 57.00 \\
\hline Universality $(\mathrm{U})^{(* * *)}$ & 1 & 2.50 & 0 & - & 0 & . & 0 & - & 0 & - & 0 & - \\
\hline TOTAL & 79 & 61.67 & 47 & 688.24 & 18 & 9.75 & 3 & 124.80 & 35 & 12.62 & 7 & 116.00 \\
\hline
\end{tabular}

\footnotetext{
${ }^{(*)}$ Refers to environmental damages resulting from actions of a particular person.

${ }^{(* *)}$ Refers to environmental damages resulting from actions of companies.

${ }^{(* * *)}$ Refers respectively to individuals whose activity is related to the family subsistence or recreation; to companies that aim the economic exploration of natural resources, or to a set of property that, in a certain special and temporary situation, receives a corporate entity so as to fulfill an economic and legal objective, becoming responsible for legal acts performed (De PLÁCIDO e SILVA, 1999).
} 
This resulted from the initial expansion of the coffee culture, partially replaced by the agricultural diversification related to corn, orange, rice and tomato cultivation, with strong prevalence of the sugar cane culture occupying pasture and savanna areas.

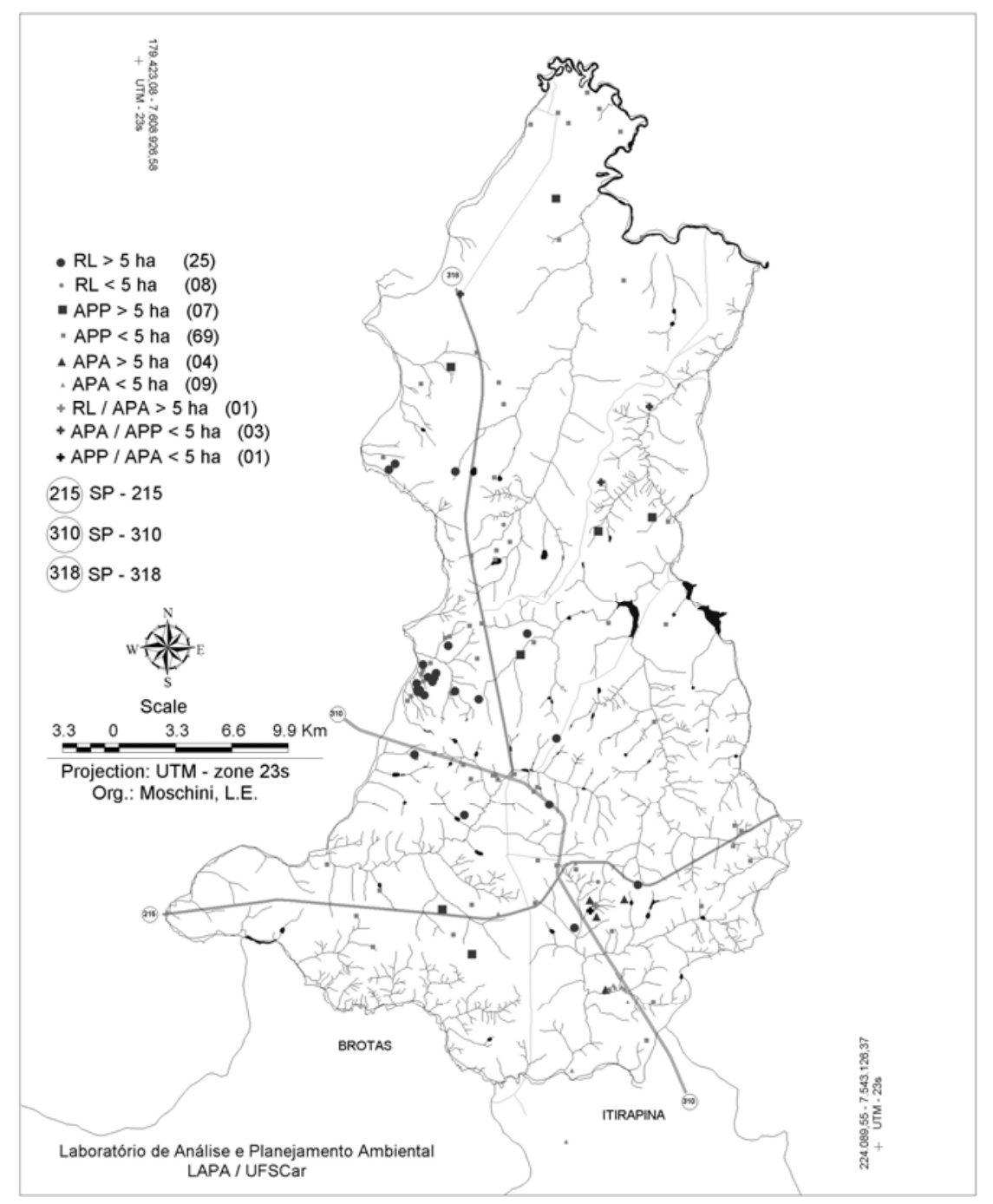

Figure 3 - Georeferenced deforestation occurrences (127), with values $<$ and $>$ that 5 ha, related to Environmental Protection Areas (APA), Permanent Protection Areas (APP) and Legal Reserve (RL) areas overlaying on the river network and road network thematic maps of São Carlos municipality, SP, during the period from 1991 to 2000. The (+) symbols indicate 05 incorrect registers when considering infractions deforestation related to legally protected areas. The correct registers are between brackets. SP-215: Luiz Augusto de Oliveira Highway. SP-310: Washington Luiz Highway. SP-318: Eng. Thales de Lorena Peixoto Highway. 


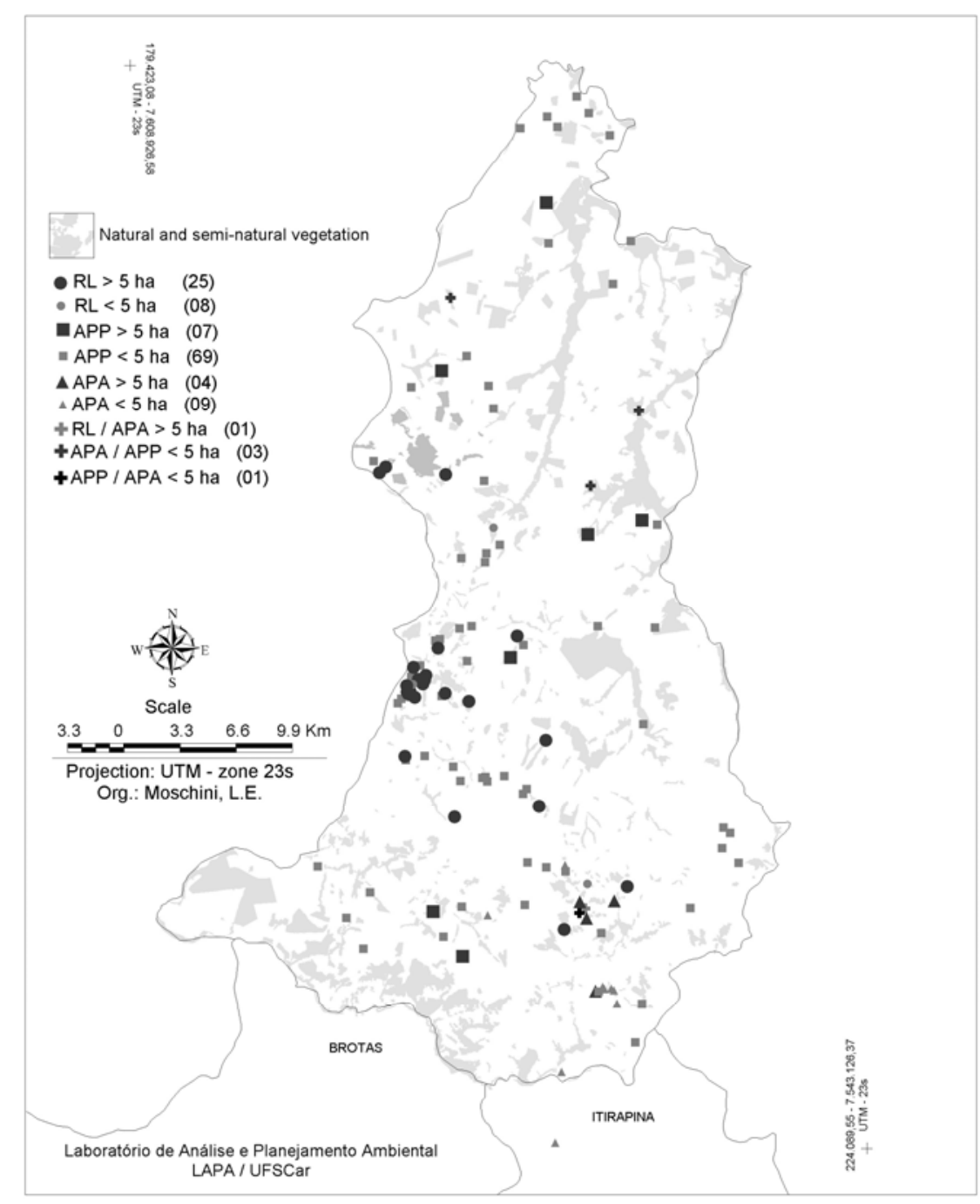

Figure 4 - Georeferenced deforestation occurrences (127), with values $<$ and $>$ that 5 ha, related to Environmental Protection Areas (APA), Permanent Protection Areas (APP) and Legal Reserve (RL) areas overlaying on the land cover thematic map of the natural e seminatural vegetation of São Carlos municipality, SP, during the period from 1991 to 2000. The (+) symbols indicate 05 incorrect registers when considering deforestation actions related to legally protected areas. The correct registers are between brackets.

The geographic location of deforestation occurrences related to APP, APA and RL areas, $<$ and $>$ than 5 ha, overlayed on the land cover thematic map, showed some incorrect registers (+) by the responsible agent for the infraction (Fig. 4). For example, when considering deforestation actions in APA areas in the Northern region of São Carlos municipality. APA's area occurred only in the south region bordering the municipalities of Brotas and Itirapina. From 1998 to 2000, at least 88 deforestation infractions were registered, resulting in the total loss of 295.05 ha of the remaining vegetation (Fig. 2), with the reduction of it to $14.1 \%$ of São Carlos municipality total area. Apparently, about 100 ha/year of natural and seminatural vegetation of São Carlos municipality, based only on the registers of chargings of deforestation in the period 1991 to 2000 were converted for agricultural use for cattle raising or even for the selective cutting of wood.

The current development trajectory did not occur without causing impacts; however, they were not providing benefits the way they should have. The loss of vegetation continued to increasingly. The evidence available suggested that their continuity enabled much more economic benefits than those 
obtained from the agricultural conversion and expansion of the land use. The natural environment provide benefits for society in various ways: through the environmental functions it contributed to climate regulation, soil formation, nutrient cycling, and supply of fuel, fibers and pharmaceutical substances (Balmford et al., 2002). These benefits should encourage the nature conservation in face of the increasing economic pressures on the natural environment, although their socio-economic evaluation was a difficult process (Santos et al., 2001) and not incorporated in the conventional economic activity, based mainly on the market analysis.

The database registers did not have information to estimate what fraction of the deforested areas, particularly those higher than 5 ha, was reoccupied by natural vegetation or left in the landscape in different degrees of deterioration. In any way, these possibilities have been considered to be very distinct in relation to the natural vegetation still remaining, not configuring an appropriate compensation in face of the loss of habitat.

\section{CONCLUSIONS}

Economic growth does not respect limits or rules, exceeding significantly the capacity of recomposition of the natural resources. Only in the São Carlos municipality, it was verified that the remaining natural and seminatural vegetation constitutes $14.1 \%$ of its total area. This value puts the landscape environmental quality in a worrying scenery, when considering that infractions deforestation are underestimated and do not correspond with the actual scenery of the municipality land use.

All inspection agencies approached in this study were unanimous to affirm that the real occurrences of environmental damages in the Administrative Region of São Carlos are much higher than those effectively registered in the State Prosecutor's Office. This happens due to the lack of denouncement and from the poor conditions of the monitoring agencies, as a consequence of equipment availability and a small number of agents to guarantee the supervision of such extensive area. The essential question is how to adjust the economic development with environmental protection, when considering it to be one of the guiding principles of economic order. Regardless of the facts that encouraged this guidelines, it is determined that all acts, with no exception, no matter if they are rights or duties, are ruled by a corresponding legislation. This includes those activities that affect nature, directly or indirectly.

The protection of the natural property legally can consider the need of a preventive environmental practice that requires not only the defense against imminent damages, but that also encourages the protection and regular use of the natural resources. Environmental Law appears with the aim to limit nature's devastation, through the legal system. Although this knowledge area of law conflicts with the various ideological divergences, coming from social, economic and cultural influences, the reasonability of decisions has been accepted. However, in order to reach the desired awareness, it is necessary to refine the legislation, even in relation to the announcement both of the content of the law and their reasons and effects.

The need of changes in behavior, prioritizing the defense and inspection of natural resources is also urgent. Solutions demand that land owners respect the legal limits, register the area intended to Legal Reserve, as well as being concerned with the importance of watching for a healthy environment, even as a way to increase the value of their products. In relation to big land owners, usually acting in the form of Corporation Entities and causing the highest environmental damages, it is necessary that they act according to the legislation in force. Otherwise, they may be legally penalized in the amount corresponding to the damages, so that they feel the effects in the economic context of their companies. This punitive approach must be associated with a development performance that is congruent with environmental sustainability, aiming to obtain a permanent financial return, but that does not lead to the natural resources and environmental quality degradation.

Another aspect to point out is the seriousness with which we must see the environmental protection programs, aimed, mainly, at the small land owners. Environmental rules, their limits, forecasts and penalties must be announced to them, because most of these owners are unaware of the aspects involved, contributing with the environmental resources degradation, particularly in relation to the riverheads. It is essential that land owners change their attitude. Not because they fear the penalties and legal restrictions, but with the aim of 
preservation, trying to avoid the environmental damage, many times irreparable.

The rupture of resistances to corrective measures must be achieved through the interactive action between the agencies of inspection and legal defense of the environment. There should pay attention to the acquisition of equipment to inspections, as well as to contract new employees and their continuous training, because of the small number of forest policemen and specialized technicians responsible for the inspection. Together with the expectation created around the inclusion of the environment protection by the legal system, the role of the State Prosecution Service in relation to the environmental protection resources is also questioned, because it is the legitimated agency before justice to defend them. An important aspect to be approached and developed by this agency, during the legal procedure of the AP and PCS, is the speed in the inquiry of occurrences, trying to prioritize the damage prevention in face of its repair. Several occurrences reveal long periods of time between the date of instauration of the legal document related to a specific environmental damage and its real occurrence in the environment. This lag fase represents a decisive factor in the attempt to avoid more significant losses, even for reestablishing the impacted environmental resource.

There is a need of integration between the responsible agents for the environment inspection and those who should protect it legally, making the confirmation of the denouncement and its punishment more efficient. Also should be point out the performance of the State Prosecution Service of São Carlos, which has been able to adjust commitment terms with their respective infractors in the last years, guaranteeing not only the repair of the impacted place, when possible, but also the register of more areas to compose the due legal forest reserve in each property registered.

Although the natural resources preservation represents the determining factor to guarantee life and environmental quality, the economic forces are the main factor of the man-environmentinterrelationship. Therefore, it is not about the non-existence of rules to limit the environmental exploration, because there are enough rules in Brazil, nor there is a lack of agencies associated with the environment protection. The difficulty is in guaranteeing the maintenance of environmental quality, in the perspective to prioritize the action of inspections and punishments related to the natural resources conservation, as a way to achieve an economic development that is more balanced with the natural resource and landscape sustainability.

\section{RESUMO}

Foi realizada a análise qualitativa e quantitativa das ocorrências de danos ambientais através dos instrumentos jurídicos instaurados pelo Ministério Público Estadual da cidade de São Carlos, SP, para a compreensão da interação entre os problemas ambientais e as ações desenvolvimentistas na paisagem local. no período de 1991-2000. Os danos ambientais foram agrupados em nove classes, sendo desmatamento o de maior ocorrência em cada ano e ao longo do período de estudo. Cerca de 180 ocorrências de desmatamento estão relacionadas com áreas menores que 5 ha, com predomínio da atuação de Pessoas Físicas, correspondendo a 110,35 ha de área desmatada no período. As 37 ocorrências restantes estão associadas com áreas maiores que 5 ha, totalizando 1.013,27 ha de área desmatada. Em uma estimativa grosseira estes valores

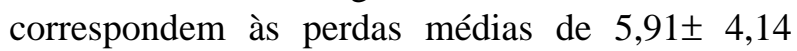
ha/ocorrência e de 112,36 \pm 91,73 ha/ano de área desmatada.

\section{REFERENCES}

Achard, F.; Eva, H. D.; Stibig, H. J.; Mayaux, P.; Gallego, J.; Richards, T. and Malingreau, J. P. (2002), Determination of deforestation rates of the world"s humid tropical forests. Science, 297, 999-1002.

Balmford, A.; Bruner, A.; Cooper, P.; Costanza, R.; Farber, S.; Green, R. E.; Jenkins, M.; Jefferiss, P.; Jessamy, V.; Madden, J.; Munro, K.; Myers, N.; Naeem, S.; Paavola, J.; Rayment, M.; Rosendo, S.; Roughgarden, J; Trumper, K. and Turner, R. K. (2002), Economic Reasons for Conserving Wild Nature. Science, 297, 950-953.

De Groot, R. S. (1992), Functions of nature. Amsterdan: Wolters-Noordhoff. 315 pp.

De Plácido e Silva (1999), Vocabulário Jurídico. Rio de Janeiro: Forense.

Dobson, A. P.; Bradshaw, A. D. and Baker, A. J. M. (1997), Hopes for the future: Restoration Ecology and Conservation Biology. Science, 277, 515-522. 
Fundação SOS Mata Atlântica; Instituto Nacional de Pesquisas Espaciais and Instituto Sócio Ambiental (1998), Atlas da Evolução dos remanescentes florestais e ecossistemas associados no domínio da Mata Atlântica no período 1990-1995. SOS Mata Atlântica, INPE and ISA. 49 pp.

Graf, A. C. B. (1998), O Direito à Informação Ambiental. Curitiba: Juruá.

Harris, L. D. (1984), The fragmented forest: island biogeography theory and the preservation of biotic diversity. Chicago: University of Chicago.

IBGE (2000), Senso Demográfico. São Paulo: Fundação Instituto de Geografia e Estatística.

MacArthur, R. H. and Wilson, E. O. (1967), The Theory of Island Biogeography. New Jersey: Princeton University.
Santos, J. E.; Nogueira, F.; Pires, J. S. R.; Obara, A. T. and Pires, A. M. Z. C. R. (2001), The value of the Ecological Station of Jatai's ecosystem services and natural capital. Brazilian Journal of Biology, 61 : (2), 171-190.

São Carlos (Município) (2000), Plano Municipal de Desenvolvimento Agropecuário Plurianual. Secretaria da Agricultura de São Carlos.

Viana, V. M.; Tabanez, A. A. J. and Batista J. L. F. (1997), Dynamics and restoration of Forest fragments in Brazil's Atlantic Coastal Forests. In: Greenberg, R. and Schellas, J. (Eds.). Forest Remnants in the Tropical Landscape. Washington, DC: Island Press. pp. 215-229. 